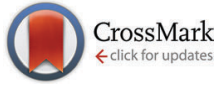

Cite this: Phys. Chem. Chem. Phys., 2016, 18, 13173

Received 28th March 2016, Accepted 25th April 2016

DOI: $10.1039 / \mathrm{c} 6 \mathrm{cp} 02034 \mathrm{~h}$

www.rsc.org/pccp

\section{In situ temperature measurements of reaction spaces under microwave irradiation using photoluminescent probes $\dagger$}

\author{
Taishi Ano, Fuminao Kishimoto, $\$$ Ryo Sasaki, Shuntaro Tsubaki, * \\ Masato M. Maitani, § Eiichi Suzuki and Yuji Wada*
}

\begin{abstract}
We demonstrate two novel methods for the measurement of the temperatures of reaction spaces locally heated by microwaves, which have been applied here to two example systems, i.e., $\mathrm{BaTiO}_{3}$ particles covered with a $\mathrm{SiO}_{2}$ shell $\left(\mathrm{BaTiO}_{3}-\mathrm{SiO}_{2}\right)$ and layered tungstate particles. Photoluminescent (PL) probes showing the temperaturesensitivity in their PL lifetimes are located in the nanospaces of the above systems. In the case of $\mathrm{BaTiO}_{3}-\mathrm{SiO}_{2}$ core-shell particles, rhodamine $\mathrm{B}$ is loaded into the mesopores of the $\mathrm{SiO}_{2}$ shell covering the $\mathrm{BaTiO}_{3}$ core, which generates the heat through the dielectric loss of microwaves. The inner nanospace temperature of the $\mathrm{SiO}_{2}$ shell is determined to be $28^{\circ} \mathrm{C}$ higher than the bulk temperature under microwave irradiation at $24 \mathrm{~W}$. On the other hand, $\mathrm{Eu}^{3+}$ is immobilized in the interlayer space of layered tungstate as the PL probe, showing that the nanospace temperature of the interlayer is only $4{ }^{\circ} \mathrm{C}$ higher than the bulk temperature. This method for temperature-measurement is powerful for controlling microwave heating and elucidates the ambiguous mechanisms of microwave special effects often observed in chemical reactions, contributing greatly to the practical application of microwaves in chemistry and materials sciences.
\end{abstract}

\section{Introduction}

Microwave irradiation has been attracting a lot of interest in chemistry and materials science as a useful tool for shortening the reaction and processing durations, and reducing temperatures. When microwaves pass through a solid, microwave energy is converted to thermal energy, i.e., heat generation due to

Department of Applied Chemistry, Tokyo Institute of Technology, 2-12 Ookayama,

Meguro, Tokyo 152-8552, Japan. E-mail: tsubaki.s.aa@m.titech.ac.jp,

yuji-w@apc.titech.ac.jp; Fax: +81-3-5734-2879; Tel: +81-3-5734-2879

$\dagger$ Electronic supplementary information (ESI) available: In situ PL decay measurement system under microwaves, characterizations of the particles, in situ PL lifetime measurements with the particles and homogeneous solution, verification of the temperature-measuring method. See DOI: 10.1039/c6cp02034h

\$ Research Fellow of Japan Society for the Promotion of Science.

$\S$ Present address: Research Center for Advanced Science and Technology (RCAST), The University of Tokyo, 4-6-1, Komaba, Meguro, Tokyo 153-8904, Japan. dielectric loss, ${ }^{1}$ magnetic loss and Joule loss. Unlike conventional heating methods, microwaves heat solids directly, resulting in rapid heating, superheating, and substance-selective heating, which induce specific temperature distribution in the heated systems. $^{2-12}$ However, it has also raised some controversial discussions on these advantages in using microwaves by often being called "microwave special effects" based on unusual experimental results which could not be explained fully by the heat generation due to microwaves. ${ }^{13-18}$ Recently, Wada's group reported the acceleration of photo-induced electron transfer by microwaves observed for photoexcited CdS quantum dots. ${ }^{18}$ "Microwave special effects" also called "non-thermal effects" have caused a controversy among microwave chemists. It was pointed out that the reports showing the non-thermal effects were often based on inaccurate temperature measurements. Kappe et al. demonstrated that infrared sensors often detected the temperature of the outer surface of a reaction vessel which was different from the temperature of the inner reaction field in the reaction vessel. ${ }^{19,20}$

We can find some challenging trials to estimate the accurate temperature of reaction fields heated by microwaves. Sumerlin et al. demonstrated the temperature distribution of the surroundings nearby Au nanoparticles after microwave irradiation at $100 \mathrm{~W}$ by using a PL probe and azo-bond. ${ }^{21}$ The temperature difference between the particle and the surrounding was estimated to be $70{ }^{\circ} \mathrm{C}$ at a distance of $0.5 \mathrm{~nm}$ from the particle surface, but it was $0{ }^{\circ} \mathrm{C}$ at that of $2 \mathrm{~nm}$. Wada et al. observed nonequilibrium local heating of cobalt metal particles by measuring the Raman spectra of the surrounding molecules as a temperature probe under microwave irradiation. ${ }^{22}$ The Co particles were dispersed in dimethylsulfoxide (DMSO) solvent, and the temperature of the DMSO molecules in close proximity to the Co surface was determined to be higher by $70{ }^{\circ} \mathrm{C}$ compared to the bulk temperature at the maximum. However, an in situ method for the measurement of the accurate temperature has yet to be developed for understanding the "microwave special effects".

We focused on the PL probes whose PL lifetimes are sensitive to temperature as the contactless molecular thermometers. ${ }^{23-27}$ 
This study demonstrates in situ temperature-measurement methods based on the temperature dependence of the PL lifetimes of probe molecules under microwave irradiation for two submicroparticle systems: $\mathrm{BaTiO}_{3}-\mathrm{SiO}_{2}$ core-shell particles and layered tungstate particles intercalated with ammonium cations $\left(\mathrm{C}_{16} \mathrm{~N}^{+}-\mathrm{W}_{2} \mathrm{O}_{7}{ }^{2-}\right)$. The $\mathrm{BaTiO}_{3}$ core is ferroelectric acting as a microwave absorber ${ }^{28}$ and the $\mathrm{SiO}_{2}$ shell provides $\mathrm{BaTiO}_{3}$ with mesopores functioning as a reaction space accommodating the reaction molecules. The $\mathrm{SiO}_{2}$ shell is transparent to microwaves and has low thermal conductivity, leading to the accumulation of heat generated in the $\mathrm{BaTiO}_{3}$ core. We loaded $\mathrm{RhB}$ as the $\mathrm{PL}$ probe in the $\mathrm{SiO}_{2}$ mesopores to measure the nanospace temperature of the inner $\mathrm{SiO}_{2}$ shell (denoted as $\mathrm{BaTiO}_{3}$ $\mathrm{RhB} @ \mathrm{SiO}_{2}$ hereafter). The layered tungstate in $\mathrm{C}_{16} \mathrm{~N}^{+}-\mathrm{W}_{2} \mathrm{O}_{7}{ }^{2-}$, reported recently as a new material, absorbs microwaves strongly. ${ }^{29}$ Ammonium cations are intercalated into the interlayer for compensating the $\mathrm{W}_{2} \mathrm{O}_{7}{ }^{2-}$ anion layer. This interlayer with a distance of several nanometers acts as a reaction space for photocatalysis. We immobilized the $\mathrm{Eu}^{3+}$ cation as the PL probe in the interlayer via ion exchange of three $\mathrm{C}_{16} \mathrm{~N}^{+}$cations with one $\mathrm{Eu}^{3+}$ (denoted as $\mathrm{C}_{16} \mathrm{~N}^{+}-\mathrm{W}_{2} \mathrm{O}_{7}{ }^{2-}-\mathrm{Eu}^{3+}$ hereafter). $\mathrm{BaTiO}_{3}-$ $\mathrm{RhB} @ \mathrm{SiO}_{2}$ and $\mathrm{C}_{16} \mathrm{~N}^{+}-\mathrm{W}_{2} \mathrm{O}_{7}{ }^{2-}-\mathrm{Eu}^{3+}$ were dispersed in heptane respectively as in heterogeneous catalysis systems which can utilize the microwave energy very efficiently in their catalytic reactions. In these particles, non-equilibrium local heating can occur effectively, leading to the dramatic acceleration of chemical reactions under microwave irradiation. The purpose of this work is to demonstrate a trial of measuring the temperatures of the nanospaces expected to work as reaction fields under microwave irradiation.

\section{Experimental}

$\mathrm{BaTiO}_{3}-\mathrm{SiO}_{2}$ core-shell particles were synthesized via a procedure adapted from the Stober method. ${ }^{30}$ Barium titanate (Wako Pure Chemical Industries Ltd., $162 \mathrm{mg}$ ) was dispersed in a mixture of ultra-pure water $(0.84 \mathrm{ml})$ and ethanol $(4.32 \mathrm{ml})$ under ultrasonification for 15 minutes. After hexadecyl trimethyl ammonium bromide (Tokyo Chemical Industry Co., Ltd., $0.91 \mathrm{mg}$ ) was added into this dispersion, the ultrasonic dispersion was conducted again for 15 minutes. While the mixture was being stirred using a stirring bar, ammonia water (Wako Pure Chemical Industries, Ltd., $15.54 \mu \mathrm{l}$ of $28 \%$ ) and tetraethyl orthosilicate (Tokyo Chemical Industry Co., Ltd., $315 \mu \mathrm{l}$ ) were added. The mixture was heated at $40{ }^{\circ} \mathrm{C}$ in 12 hours under stirring. The resulting powder was washed with water and ethanol and dried under vacuum, giving $\mathrm{BaTiO}_{3}-\mathrm{SiO}_{2}$ core-shell particles. $\mathrm{RhB}$ was introduced into the mesopores of the $\mathrm{SiO}_{2}$ shell using an immersion method for obtaining $\mathrm{BaTiO}_{3}-\mathrm{RhB} @ \mathrm{SiO}_{2} \cdot \mathrm{BaTiO}_{3}-\mathrm{SiO}_{2}$ particles were immersed in $\mathrm{RhB}(\geq 95 \%$, Sigma-Aldrich Co.) aqueous solution $(0.3 \mathrm{ml}$ of $0.1 \mathrm{mM} \mathrm{RhB})$ under ultrasonication for 30 minutes. The red-coloured powder was washed with water until the supernatant liquid became colourless. The powder was dried, giving $\mathrm{BaTiO}_{3}-\mathrm{RhB} @ \mathrm{SiO}_{2}$.

$\mathrm{H}_{2} \mathrm{~W}_{2} \mathrm{O}_{7}$ was synthesized via a procedure reported in ref. 29. A mixture of bismuth(III) oxide (Wako Pure Chemical Industries,
Ltd., $15.1 \mathrm{~g}$ ) and tungsten(III) oxide (Kojundo Chemical Laboratory Co., Ltd., $15.0 \mathrm{~g}$ ) was calcined at $800{ }^{\circ} \mathrm{C}$ for 20 hours, giving $\mathrm{Bi}_{2} \mathrm{~W}_{2} \mathrm{O}_{9}$, as a precursor of $\mathrm{H}_{2} \mathrm{~W}_{2} \mathrm{O}_{7}$. Then, $\mathrm{Bi}_{2} \mathrm{~W}_{2} \mathrm{O}_{9}(10 \mathrm{~g})$ was dispersed in $6 \mathrm{M}$ hydrochloric acid, and heated by microwaves using MicroSYNTH (Milestone Inc.) at $80{ }^{\circ} \mathrm{C}$ for one hour. The resulting powder was washed with water, dried for 6 hours under vacuum and then dried under air for 1 day, giving $\mathrm{H}_{2} \mathrm{~W}_{2} \mathrm{O}_{7}$. Hexadecylamine was intercalated into $\mathrm{H}_{2} \mathrm{~W}_{2} \mathrm{O}_{7}$, giving $\mathrm{C}_{16} \mathrm{~N}^{+}-$ $\mathrm{W}_{2} \mathrm{O}_{7}{ }^{2-}$, through the acid-base reaction of hexadecylamine with protons in the interlayer to form hexadecylammonium cations. A mixture of $\mathrm{H}_{2} \mathrm{~W}_{2} \mathrm{O}_{7}(1.0 \mathrm{~g})$ and hexadecylamine (Tokyo Chemical Industry Co., Ltd., $5.0 \mathrm{~g}$ ) in $50 \mathrm{ml}$ of heptane was stirred for 6 hours at room temperature. The resulting powder was washed with acetone three times, dried for 6 hours under vacuum, and then dried under air for 1 day, giving $\mathrm{C}_{16} \mathrm{~N}^{+}-\mathrm{W}_{2} \mathrm{O}_{7}{ }^{2-} \cdot \mathrm{C}_{16} \mathrm{~N}^{+}-$ $\mathrm{W}_{2} \mathrm{O}_{7}{ }^{2-}-\mathrm{Eu}^{3+}$ was obtained via an ion exchange of three $\mathrm{C}_{16} \mathrm{~N}^{+}$ cations with one $\mathrm{Eu}^{3+}$. A mixture of $\mathrm{C}_{16} \mathrm{~N}^{+}-\mathrm{W}_{2} \mathrm{O}_{7}{ }^{2-}(0.50 \mathrm{~g})$ and europium(III) chloride hexahydrate (Kanto Chemical Co. Inc., $1.27 \mathrm{~g}$ ) in $50 \mathrm{ml}$ of $50 \%$ ethanol water was stirred for 48 hours at room temperature. The resulting powder was washed with water and ethanol, giving $\mathrm{C}_{16} \mathrm{~N}^{+}-\mathrm{W}_{2} \mathrm{O}_{7}{ }^{2-}-\mathrm{Eu}^{3+}$ after drying.

Scanning electron microscopy (SEM) images and a crosssectional SEM image were collected using an S-5500 (Hitachi High-Technologies Co.). The sample for the cross-sectional SEM was obtained by $\mathrm{Ar}^{+}$sputtering with an $\mathrm{Al}$ substrate using an SM-09020CP (JEOL Ltd.), and modified using a conductive surface, $2 \mathrm{~nm}$ thickness of $\mathrm{OsO}_{4}$. Cross-sectional transmission electron microscopy (TEM) images were collected using a JEM-2010 (JEOL Ltd.). The sample was sliced using UMT-UC7 ultramicrotomes (Leica Microsystems $\mathrm{GmbH}$ ). Nitrogen adsorption was measured using a Belsorp-mini (MicrotracBEL Co.). The samples were purged by $\mathrm{N}_{2}$ gas at $423 \mathrm{~K}$. The UV-vis spectra were collected using a V-670 (JASCO Co.) equipped with a diffused reflex unit, ISN-470 (JASCO Co.). The emission spectra and excitation spectra were collected using a F-7000 (Hitachi HighTechnologies Co.). X-ray diffraction spectra (XRD) were collected using a Miniflex (Rigaku Co.) and X'Pert MPD-OEC diffractometer (PANalytical B.V.). Elemental analysis was conducted using a CHN corder MT-6 (Yanaco Technical Science Co., Ltd.) and Prodigy ICP (ICP-OES) (Teledyne Leeman Labs). For ICP-OES, the sample was dissolved in a mixture of hydrofluoric acid, hydrochloric acid and nitric acid.

In situ temperature measurements of the reaction nanospaces were conducted as described below. $\mathrm{BaTiO}_{3}-\mathrm{RhB} @ \mathrm{SiO}_{2}$ $(100 \mathrm{mg})$ or $\mathrm{C}_{16} \mathrm{~N}^{+}-\mathrm{W}_{2} \mathrm{O}_{7}{ }^{2-}-\mathrm{Eu}^{3+}(20 \mathrm{mg})$ dispersed in heptane $(4 \mathrm{ml})$ was placed in a rectangular four-sided quartz cell with an optical length of $1 \mathrm{~cm}$.

For the measurement of PL under conventional heating, the above cell was placed in a spectroscopic cryostat, Coolspek UV (Unisoku Co. Ltd.), with a temperature control unit, CS-AT-HT (Unisoku Co. Ltd.). This cryostat was set at the measuring position in a PL lifetime measuring instrument, QuantaurusTau (Hamamatsu Photonics K.K.). Solutions were stirred using a cuboid bar $(1 \mathrm{~mm} \times 1 \mathrm{~mm} \times 8 \mathrm{~mm})$ during the measurements. The temperatures of the bulk solutions were measured using a fiber-optic thermometer. 
The PL lifetimes were derived by fitting the PL decays to a one component exponential function, taking the instrument response function obtained using a colloidal silica, Ludox ${ }^{\circledR}$ HS40 (SigmaAldrich Co.) dispersion in water. For $\mathrm{BaTiO}_{3}-\mathrm{SiO}_{2}$, the PL decay in a 3.6 to 10.1 ns range was used to determine the PL lifetime by fitting. For $\mathrm{C}_{16} \mathrm{~N}^{+}-\mathrm{W}_{2} \mathrm{O}_{7}{ }^{2-}-\mathrm{Eu}^{3+}$, the PL decay from 100 to $502 \mu \mathrm{s}$ was used. For the in situ temperature measurements of the PL decays under microwave irradiation, the same equipment as that previously reported by our group ${ }^{18}$ (Fig. S1, ESI $\dagger$ ) was used. An ellipsoid microwave applicator (Chronix Ltd.) and a PL lifetime measuring instrument, Quantaurus-Tau, were assembled to form a system for in situ measurements of PL under microwave irradiation as shown in Fig. S1a and b (ESI $\dagger$ ). The above cell was placed in the chamber of the microwave applicator. The chamber was drilled to permit a PL path. The fiber-optic thermometer was inserted into the cell and placed at the upper position of the cell where microwaves were not applied. The solutions were stirred using a cuboid bar $(1 \mathrm{~mm} \times 1 \mathrm{~mm} \times 8 \mathrm{~mm})$ during measurements.

The PL lifetimes under continuous microwave irradiation were measured many times continuously during the microwave irradiation. To minimize the variation of the temperatures, all measurements of the PL decays were conducted setting the cell at the same conditions, i.e., position, stirring rate and PL counts. Especially, it should be emphasized that PL measurements were carried out $10 \mathrm{~min}$ after starting the stirring of the solutions for stabilizing the optical conditions of the solutions.

\section{Results and discussion}

The preparation scheme of $\mathrm{BaTiO}_{3}-\mathrm{RhB} @ \mathrm{SiO}_{2}$ core-shell particles is shown in Fig. 1a. The core size distribution of $\mathrm{BaTiO}_{3}-\mathrm{RhB} @ \mathrm{SiO}_{2}$ (Fig. 1b) was determined from the SEM images of $\mathrm{BaTiO}_{3}$ as the precursor (Fig. S4, ESI $\dagger$ ). The shell thickness distribution of $\mathrm{BaTiO}_{3}-\mathrm{RhB} @ \mathrm{SiO}_{2}$ (Fig. 1c) was determined from the cross-section of the TEM image of $\mathrm{BaTiO}_{3}-\mathrm{SiO}_{2}$ (Fig. S5, ESI $\dagger$ ). The cross-sectional SEM image is also shown in Fig. S6 (ESI $\dagger$ ). These observations gave the averages of the core size and the shell thickness of $\mathrm{BaTiO}_{3}-\mathrm{SiO}_{2}$ as $447 \mathrm{~nm}$ and $10.4 \mathrm{~nm}$, respectively. The nitrogen adsorption isotherms of $\mathrm{BaTiO}_{3}$ and $\mathrm{BaTiO}_{3}-\mathrm{SiO}_{2}$ were shown to be of III type (Fig. S7, ESI $\dagger$ ), essentially indicating the absence of pore structures in these particles. However, the hysteresis and the increased adsorption observed at high $P / P_{0}$ for the isotherm of $\mathrm{BaTiO}_{3}-\mathrm{SiO}_{2}$ showed that the $\mathrm{SiO}_{2}$ shell of $\mathrm{BaTiO}_{3}-\mathrm{SiO}_{2}$ contained mesopores to a certain extent. The amount of $\mathrm{RhB}$ loaded in $\mathrm{BaTiO}_{3}-\mathrm{SiO}_{2}$ was calculated to be $183 \mathrm{mmol} \mathrm{g}^{-1} \mathrm{BaTiO}_{3}-\mathrm{SiO}_{2}$ from the $\mathrm{RhB}$ decrement in the immersion method using UV-vis spectroscopy. Since $\mathrm{BaTiO}_{3}-$ $\mathrm{RhB@SiO}{ }_{2}$ was washed with ultra-pure water many times, the $\mathrm{RhB}$ present on the outer surface of the $\mathrm{SiO}_{2}$ shell was removed and only $\mathrm{RhB}$ in the $\mathrm{SiO}_{2}$ mesopores remained. The excitation spectrum and the emission spectrum of $\mathrm{BaTiO}_{3}-\mathrm{RhB} @ \mathrm{SiO}_{2}$ were measured and are shown in Fig. 1d.

First we needed to obtain the relationship between the PL lifetime and the temperature in order to convert the PL lifetime to the temperature for $\mathrm{BaTiO}_{3}-\mathrm{RhB} @ \mathrm{SiO}_{2}$. PL lifetime measurements were carried out using the PL decay at $580 \mathrm{~nm}$ of RhB excited by $5 \mathrm{MHz}$ pulse LED light at $405 \mathrm{~nm}$. The PL decay was fitted using only one exponential component, giving the PL lifetime. Fig. 2a shows the PL decays of $\mathrm{BaTiO}_{3}-\mathrm{RhB@SiO}$ at 27, 40, 50, 60 and $70{ }^{\circ} \mathrm{C}$ under conventional heating. The PL lifetime value at each temperature was obtained as the average of the values repeated three times. The PL lifetimes at 27, 40, 50, 60 and $70{ }^{\circ} \mathrm{C}$ are plotted against the temperatures, giving a straight line. This relationship was used for obtaining the
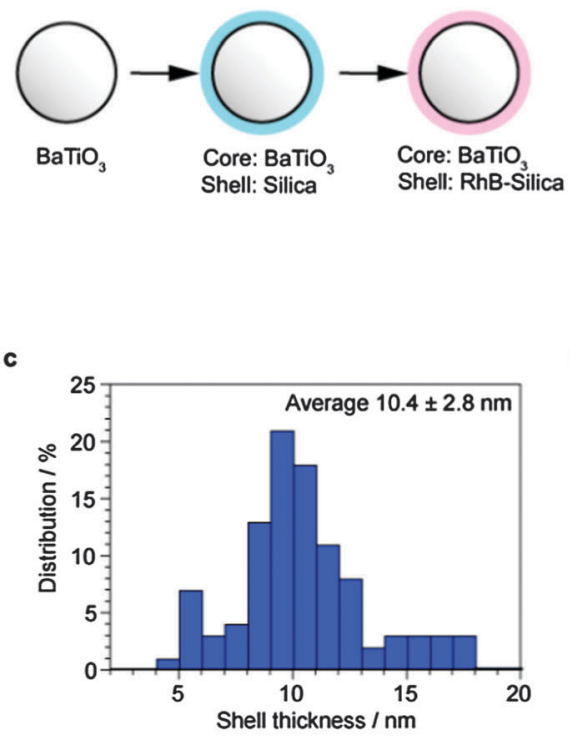

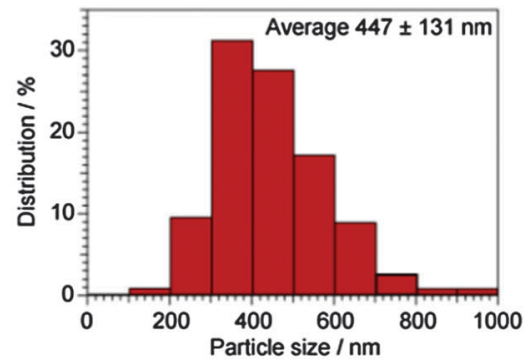

d

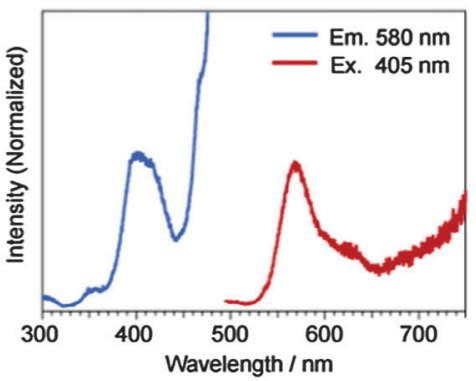

Fig. 1 Synthesis of $\mathrm{BaTiO}_{3}-\mathrm{RhBaSiO}$. (a) Synthesis scheme, (b) core size distribution, (c) shell thickness distribution, and (d) excitation spectrum and emission spectrum. 

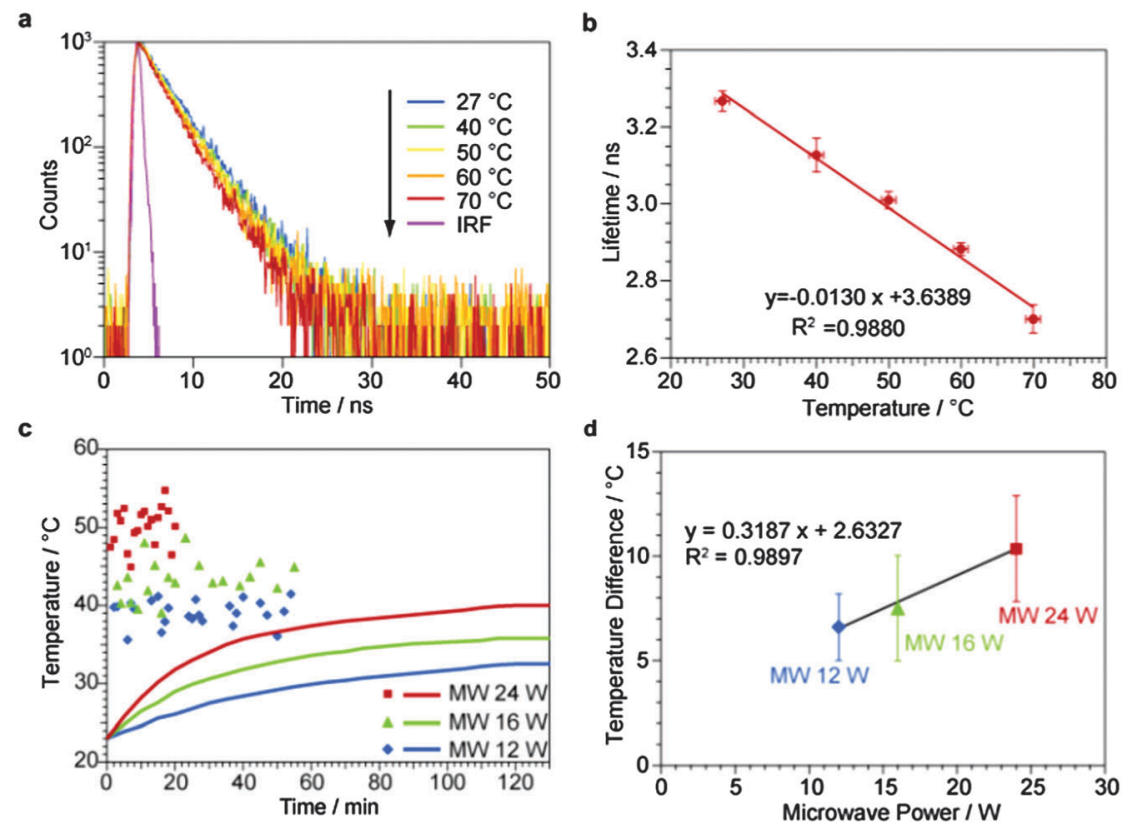

Fig. 2 In situ temperature measurements for $\mathrm{BaTiO}_{3}-\mathrm{RhBaSiO}_{2}$ under microwave irradiation. (a) $\mathrm{PL}$ decays at 27, 40,50,60 and $70{ }^{\circ} \mathrm{C}$ under conventional heating. (b) Calibration line between the lifetime and the temperature. (c) Nanospace temperatures in the $\mathrm{SiO}_{2}$ mesopores plotted against the microwave irradiation time at 12,16 and $24 \mathrm{~W}$. Bulk temperatures shown as the curves. (d) Temperature differences between the nanospace and the bulk under microwave irradiation in the stable state plotted against the microwave power.

temperature experienced by $\mathrm{RhB}$ present in the $\mathrm{SiO}_{2}$ shell of $\mathrm{BaTiO}_{3}-\mathrm{RhB}_{\mathrm{S}} \mathrm{SiO}_{2}$ under microwave irradiation. The relationship between the temperature and the PL lifetime of $\mathrm{RhB}$ in ethanol solution is shown in Fig. S8 (ESI $\dagger$ ) for comparison with the above measurements for $\mathrm{BaTiO}_{3}-\mathrm{RhB} @ \mathrm{SiO}_{2}$. It can be concluded that the sensitivity to temperature of the PL lifetime of $\mathrm{RhB}$ was reduced by adsorption in the mesopores of $\mathrm{BaTiO}_{3}-$ $\mathrm{RhB} @ \mathrm{SiO}_{2}$, probably due to the restraint of the $\mathrm{RhB}$ molecule by the interaction with the wall of the mesopores.

Now, we demonstrate the temperature-measurement of the nanospace of the mesopores of the $\mathrm{SiO}_{2}$ shell of $\mathrm{BaTiO}_{3}-$ $\mathrm{RhB} @ \mathrm{SiO}_{2}$ under microwave irradiation by measuring the PL lifetime of $\mathrm{RhB}$. When the solution of $\mathrm{BaTiO}_{3}-\mathrm{RhB} @ \mathrm{SiO}_{2}$ dispersed in heptane was irradiated by microwaves at $24 \mathrm{~W}$, the bulk temperature of the solution measured by a fiber-optic thermometer was gradually increased from 23.0 to $40.0{ }^{\circ} \mathrm{C}$ during the $130 \mathrm{~min}$ irradiation as shown by the red line in Fig. 2c. The red dots indicate the temperature obtained by the PL lifetimes obtained by using the relationship shown in Fig. $2 \mathrm{~b}$ against the microwave irradiation time. The raw data for these measurements of Fig. $2 c$ are shown in Fig. S9 (ESI $\dagger$ ). The first measurement gave a higher temperature $\left(47.5^{\circ} \mathrm{C}\right)$ than the bulk temperature $\left(24.5^{\circ} \mathrm{C}\right)$ after only $1 \mathrm{~min}$ of microwave irradiation, demonstrating the rapid increase of the nanospace temperature in the mesopores. The following measurements showed rather a large variation in the temperature values, but it should be mentioned that the temperature reached a stable state $\left(50.4{ }^{\circ} \mathrm{C}\right)$, determined by taking the average of all plots considering the standard deviation of the temperatures $\left(2.5^{\circ} \mathrm{C}\right)$. This behaviour is explained by the generation of heat in $\mathrm{BaTiO}_{3}-$ $\mathrm{RhB@SiO}{ }_{2}$ balanced with the heat flow to the solution. The bulk temperature also approached and reached the stable state $\left(40.0{ }^{\circ} \mathrm{C}\right)$, demonstrating the temperature difference of $10.4{ }^{\circ} \mathrm{C}$ remained even in the stable state between the nanospace and the bulk, in which all the heat flows were balanced in the whole system. The same experiments when carried out at 12 and $16 \mathrm{~W}$ microwave irradiation gave the similar results, and the temperature differences were $6.6^{\circ} \mathrm{C}$ and $7.5^{\circ} \mathrm{C}$, respectively. The temperature differences were plotted against the microwave powers (Fig. 2d). The linear relationship is shown between the temperature differences and microwave powers, displaying the non-equilibrium local heating in the nanospace of $\mathrm{BaTiO}_{3}-$ $\mathrm{RhB} @ \mathrm{SiO}_{2}$. After the microwave irradiation, no RhB elution from $\mathrm{BaTiO}_{3}-\mathrm{RhB} @ \mathrm{SiO}_{2}$ to heptane was confirmed due to the absence of absorption peaks of $\mathrm{RhB}$ in the supernatant liquid (Fig. S10, ESI $\dagger$ ), showing no changes of $\mathrm{BaTiO}_{3}-\mathrm{RhB}_{2} \mathrm{SiO}_{2}$ due to the microwave irradiation. We also conducted in situ temperature-measurement for a homogeneous RhB ethanol solution under microwave irradiation (Fig. S11, ESI $\dagger$ ). The lifetimes under microwave irradiation showed no differences compared to the calibration curve, i.e., the estimated temperature from the homogeneous RhB was the same as the bulk temperature measured by a fiber-optic thermometer.

The $\mathrm{C}_{16} \mathrm{~N}^{+}-\mathrm{W}_{2} \mathrm{O}_{7}{ }^{2-}-\mathrm{Eu}^{3+}$ layered structure was prepared by a scheme shown in Fig. 3a. The particle size distribution (Fig. 3b) was determined from the SEM image (Fig. S12, ESI $\dagger$ ), and then the average particle size was estimated to be $0.887 \mu \mathrm{m}$. The XRD peaks of $\mathrm{C}_{16} \mathrm{~N}^{+}-\mathrm{W}_{2} \mathrm{O}_{7}{ }^{2-}-\mathrm{Eu}^{3+}$ and its precursors are shown in Fig. 3c. The $d$ value of the 001 peak is attributed to the centerto-center distance of the tungstate layers. Ammonium cations were intercalated into the $\mathrm{C}_{16} \mathrm{~N}^{+}-\mathrm{W}_{2} \mathrm{O}_{7}{ }^{2-}$ interlayer, resulting in the distance of $4.49 \mathrm{~nm} . \mathrm{C}_{16} \mathrm{~N}^{+}-\mathrm{W}_{2} \mathrm{O}_{7}{ }^{2-}-\mathrm{Eu}^{3+}$ was obtained 
a
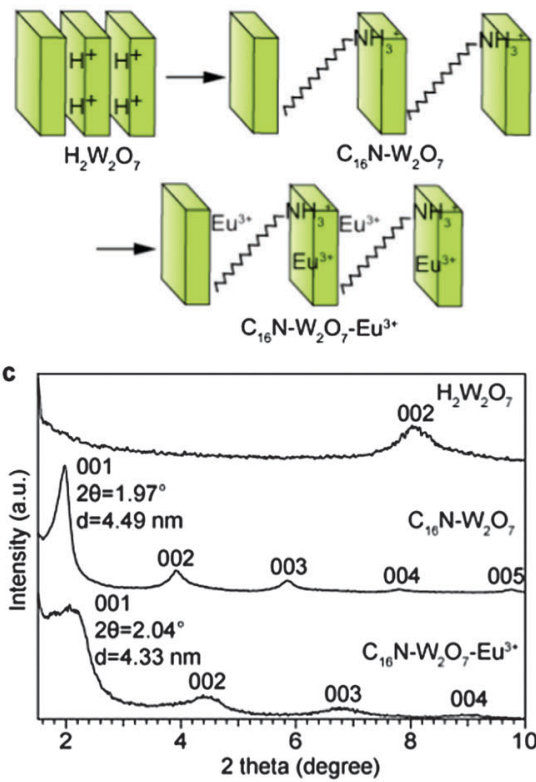
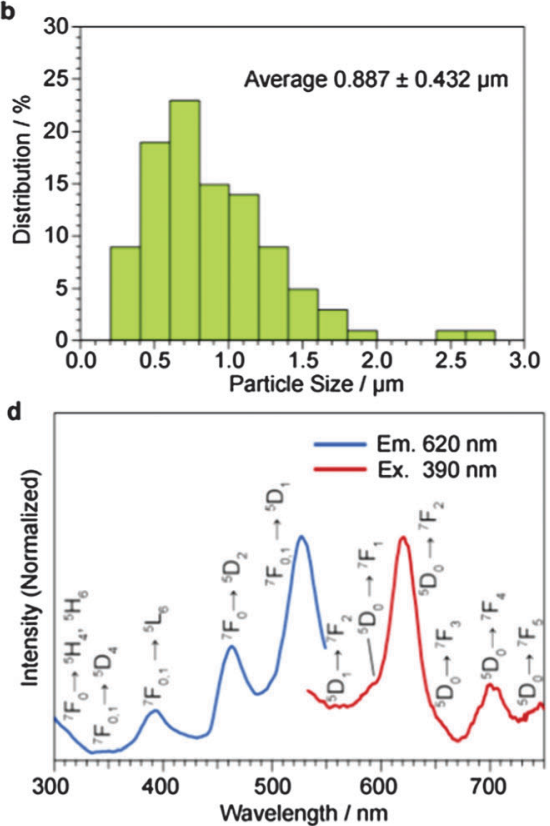

Fig. 3 Synthesis of $\mathrm{C}_{16} \mathrm{~N}^{+}-\mathrm{W}_{2} \mathrm{O}_{7}{ }^{2-}-\mathrm{Eu}^{3+}$. (a) Synthesis scheme. (b) Particle size distribution. (c) XRD peaks. (d) Excitation spectrum and emission spectrum.

through the ion exchange of $\mathrm{C}_{16} \mathrm{~N}^{+}$with $\mathrm{Eu}^{3+}$, reducing the center-to-center distance to $4.33 \mathrm{~nm}$ from the above value of $\mathrm{C}_{16} \mathrm{~N}^{+}-\mathrm{W}_{2} \mathrm{O}_{7}{ }^{2-}$. Since the thickness of a tungstate monolayer was estimated to be $0.96 \mathrm{~nm}$ in a previous report, ${ }^{31}$ the interlayer distance was determined to be $3.37 \mathrm{~nm}$. Since the length of the alkyl chain of the $\mathrm{C}_{16} \mathrm{~N}^{+}$cation is estimated to be $2 \mathrm{~nm}$ and the ionic radius of $\mathrm{Eu}^{3+}$ cation is $1 \mathrm{~nm}$, the interlayer space is wide enough to accommodate both $\mathrm{C}_{16} \mathrm{~N}^{+}$and $\mathrm{Eu}^{3+}$. No change in the XRD peaks at angles higher than $20^{\circ}$ (Fig. S13, ESI $\dagger$ ) showed no structural change in each $\mathrm{W}_{2} \mathrm{O}_{7}{ }^{2-}$ layer through the intercalation of ammonium cations and cation exchange with $\mathrm{Eu}^{3+}$. The composition of $\mathrm{C}_{16} \mathrm{~N}^{+}-\mathrm{W}_{2} \mathrm{O}_{7}{ }^{2-}-\mathrm{Eu}^{3+}$ was determined by the $\mathrm{CHN}$ analysis and ICP-OES (Table 1). The densities of $\mathrm{C}_{16} \mathrm{~N}^{+}$and $\mathrm{Eu}^{3+}$ were estimated to be 2.33 molecules $\mathrm{nm}^{-2}$ and 2.12 ions $\mathrm{nm}^{-2}$, respectively. The excitation spectrum and the emission spectrum of $\mathrm{C}_{16} \mathrm{~N}^{+}-\mathrm{W}_{2} \mathrm{O}_{7}{ }^{2-}-\mathrm{Eu}^{3+}$ were measured as shown in Fig. $4 \mathrm{~d}$.

Again, we obtained the relationship between the temperature and the PL lifetime for $\mathrm{C}_{16} \mathrm{~N}^{+}-\mathrm{W}_{2} \mathrm{O}_{7}{ }^{2-}-\mathrm{Eu}^{3+}$. PL lifetime measurements were carried out using the PL decay at $620 \mathrm{~nm}$ of $\mathrm{Eu}^{3+}$ excited by $100 \mathrm{~Hz}$ pulse light at $390 \mathrm{~nm}$ from a xenon lamp through a $390 \mathrm{~nm}$ bandpass filter. The PL decays were fitted using only one exponential component, giving the PL lifetime. Fig. 4 a shows the PL decays of $\mathrm{C}_{16} \mathrm{~N}^{+}-\mathrm{W}_{2} \mathrm{O}_{7}{ }^{2-}-\mathrm{Eu}^{3+}$ at $22,30,40$, 50, 60 and $70{ }^{\circ} \mathrm{C}$ under conventional heating. The PL lifetime value at each temperature was obtained as the average of the values repeated five times. The PL lifetimes at 22, 30, 40, 50, 60 and $70{ }^{\circ} \mathrm{C}$ are plotted against the temperature, giving a straight line. This relationship was used for obtaining the temperature experienced by $\mathrm{Eu}^{3+}$ of $\mathrm{C}_{16} \mathrm{~N}^{+}-\mathrm{W}_{2} \mathrm{O}_{7}{ }^{2-}-\mathrm{Eu}^{3+}$ under microwave irradiation. The relationship between the PL lifetime and the temperature of $\mathrm{Eu}^{3+}$ in $80 \%$ ethanol water is shown in Fig. S14 (ESI $\dagger$ ) for comparing with the above measurements for $\mathrm{C}_{16} \mathrm{~N}^{+}-$ $\mathrm{W}_{2} \mathrm{O}_{7}{ }^{2-}-\mathrm{Eu}^{3+}$. It can be concluded that the sensitivity to temperature of the PL lifetime of $\mathrm{Eu}^{3+}$ was significantly increased by the introduction of $\mathrm{Eu}^{3+}$ into the $\mathrm{C}_{16} \mathrm{~N}^{+}-\mathrm{W}_{2} \mathrm{O}_{7}{ }^{2-}-\mathrm{Eu}^{3+}$ interlayer, probably due to some interactions of the $\mathrm{Eu}^{3+}$ molecule with the $\mathrm{W}_{2} \mathrm{O}_{7}{ }^{2-}$ layer.

Then, we demonstrate the temperature-measurement of the interlayer nanospace of $\mathrm{C}_{16} \mathrm{~N}^{+}-\mathrm{W}_{2} \mathrm{O}_{7}{ }^{2-}-\mathrm{Eu}^{3+}$ under microwave irradiation by measuring the PL lifetime of $\mathrm{Eu}^{3+}$. When the solution of $\mathrm{C}_{16} \mathrm{~N}^{+}-\mathrm{W}_{2} \mathrm{O}_{7}{ }^{2-}-\mathrm{Eu}^{3+}$ dispersed in heptane was irradiated by microwaves at $24 \mathrm{~W}$, the bulk temperature of the solution measured by a fiber-optic thermometer was gradually increased from 26.0 to $54.0{ }^{\circ} \mathrm{C}$ during the 70 min irradiation as shown by the red line in Fig. 4c. The red dots indicate the temperatures obtained at the PL lifetimes obtained using the relationship shown in Fig. $4 \mathrm{~b}$ against the microwave irradiation time. The raw data of the above measurements in Fig. 4c are shown in Fig. S15 (ESI $\dagger$ ). The second measurement gave a higher temperature $\left(31 .{ }^{\circ} \mathrm{C}\right)$ than that for the solution $\left(28.6{ }^{\circ} \mathrm{C}\right)$ after only 4 min of microwave irradiation, demonstrating the increase in the nanospace temperature of the interlayer. The following measurements showed a gradual increase in the interlayer temperature, showing rather a large dispersion in the temperature

Table 1 Chemical composition of $\mathrm{C}_{16} \mathrm{~N}^{+}-\mathrm{W}_{2} \mathrm{O}_{7}{ }^{2-}-\mathrm{Eu}^{3+}$ from $\mathrm{CHN}$ analysis and ICP-OES

\begin{tabular}{lllllllll}
\hline & $\mathrm{C} / \mathrm{wt} \%$ & $\mathrm{H} / \mathrm{wt} \%$ & $\mathrm{~N} / \mathrm{wt} \%$ & $\mathrm{O} / \mathrm{wt} \%$ & $\mathrm{~W} / \mathrm{wt} \%$ & $\mathrm{Eu} / \mathrm{wt} \%$ & $\mathrm{C}_{16} \mathrm{~N}^{+}$density/nm ${ }^{2}$ & $\mathrm{Eu}^{3+}$ density/nm \\
\hline $\mathrm{C}_{16} \mathrm{~N}^{+}-\mathrm{W}_{2} \mathrm{O}_{7}{ }^{2-}-\mathrm{Eu}^{3+}$ & 10.7 & 2.46 & 0.76 & 18.6 & 60 & 7.75 & 2.33 & 2.12
\end{tabular}


a

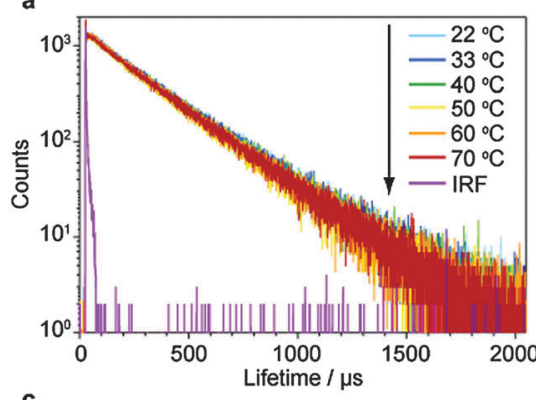

c

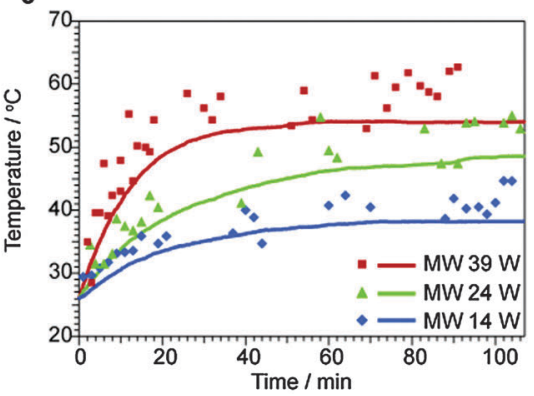

b
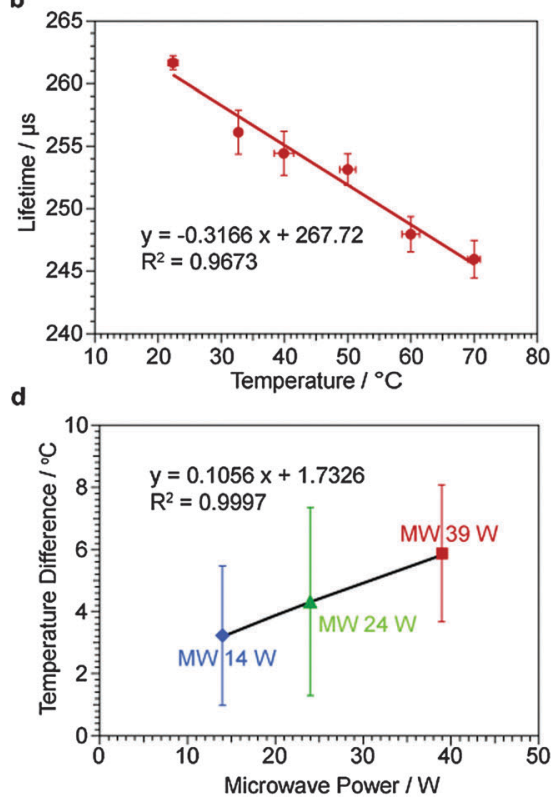

Fig. 4 In situ temperature measurements for $\mathrm{C}_{16} \mathrm{~N}^{+}-\mathrm{W}_{2} \mathrm{O}_{7}{ }^{2-}-\mathrm{Eu}^{3+}$ under microwave irradiation. (a) $\mathrm{PL}$ decays at $22,33,40,50,60$ and $70{ }^{\circ} \mathrm{C}$ under conventional heating, (b) calibration line between the lifetime and the temperature, and (c) nanospace temperatures of the $\mathrm{W}_{2} \mathrm{O}_{7}{ }^{2-}$ interlayer plotted against the microwave irradiation time at 14, 24 and $39 \mathrm{~W}$. Bulk temperatures shown as the curves. (d) Temperature differences between the nanospace and the bulk under microwave irradiation in the stable state plotted against microwave power.

values. The temperature difference of $3.7^{\circ} \mathrm{C}$ was constant with the standard deviation of $2.8{ }^{\circ} \mathrm{C}$ in the whole range of the microwave irradiation time. We regarded the last eight plots under microwave irradiation at $24 \mathrm{~W}$ as the measurements in the stable state, and obtained the temperature difference as $4.3{ }^{\circ} \mathrm{C}$ with the standard deviation of $3.0{ }^{\circ} \mathrm{C}$. The same experiments carried out at 14 and $39 \mathrm{~W}$ gave the similar results, and the temperature differences in the stable state were $3.2{ }^{\circ} \mathrm{C}$ and $5.8{ }^{\circ} \mathrm{C}$, respectively. These temperature differences were plotted against the microwave powers (Fig. 4d). A linear relationship between the temperature difference and the microwave power was observed here, showing the non-equilibrium local heating in the interlayer nanospace of $\mathrm{C}_{16} \mathrm{~N}^{+}-\mathrm{W}_{2} \mathrm{O}_{7}{ }^{2-}-\mathrm{Eu}^{3+}$.

Compared with $\mathrm{BaTiO}_{3}-\mathrm{RhB} @ \mathrm{SiO}_{2}$ under microwave irradiation at $24 \mathrm{~W}$, the temperature differences observed for $\mathrm{C}_{16} \mathrm{~N}^{+}-\mathrm{W}_{2} \mathrm{O}_{7}{ }^{2-}-\mathrm{Eu}^{3+}$ were not large. On the other hand, the increase of the bulk solution temperature under microwave irradiation was faster for $\mathrm{C}_{16} \mathrm{~N}^{+}-\mathrm{W}_{2} \mathrm{O}_{7}{ }^{2-}-\mathrm{Eu}^{3+}$ than $\mathrm{BaTiO}_{3}-$ $\mathrm{RhB} @ \mathrm{SiO}_{2}$. We attributed this result to the insufficient ability for insulating heat conduction in $\mathrm{C}_{16} \mathrm{~N}^{+}-\mathrm{W}_{2} \mathrm{O}_{7}{ }^{2-}-\mathrm{Eu}^{3+}$ causing much heat flow to the solution easily. It can be concluded that the ability of heat insulation is critical for creating non-equilibrium heating, for promoting catalysis under microwave irradiation effectively. After the microwave irradiation, no $\mathrm{Eu}^{3+}$ elution from $\mathrm{C}_{16} \mathrm{~N}^{+}-\mathrm{W}_{2} \mathrm{O}_{7}{ }^{2-}-\mathrm{Eu}^{3+}$ to heptane was confirmed due to the absence of absorption peaks of $\mathrm{Eu}^{3+}$ in the supernatant liquid (Fig. S16, $\mathrm{ESI} \dagger$ ). We also measured the SEM images (Fig. S17, ESI $\dagger$ ) to determine the particle size distribution (Fig. S18, ESI $\dagger$ ), XRD peaks (Fig. S19, ESI $\dagger$ ), and chemical composition (Table S1, ESI $\dagger$ ) of $\mathrm{C}_{16} \mathrm{~N}^{+}-\mathrm{W}_{2} \mathrm{O}_{7}{ }^{2-}-\mathrm{Eu}^{3+}$ after the microwave irradiation. These results showed no changes in the $\mathrm{C}_{16} \mathrm{~N}^{+}-\mathrm{W}_{2} \mathrm{O}_{7}{ }^{2-}-\mathrm{Eu}^{3+}$ structure and the chemical composition by the microwave irradiation. Additionally, the lifetimes of $\mathrm{C}_{16} \mathrm{~N}^{+}-\mathrm{W}_{2} \mathrm{O}_{7}{ }^{2-}-\mathrm{Eu}^{3+}$ before and after the microwave irradiation were the same as the calibration line (Fig. S20, ESI $\dagger$ ), showing that the lifetimes were not changed by the microwave irradiated time. We also conducted the in situ temperature-measurement for a homogeneous mixture of $\mathrm{Eu}^{3+}$ $80 \%$ in ethanol water (Fig. S21, ESI $\dagger$ ). The lifetimes under microwave irradiation showed no differences from the calibration line, in which the estimated temperature from the homogeneous $\mathrm{Eu}^{3+}$ was the same as the bulk temperature measured using a fiber-optic thermometer.

\section{Conclusions}

In summary, we demonstrate the in situ temperaturemeasurement of local temperatures under microwave irradiation. This method has been applied to two systems: $\mathrm{BaTiO}_{3}-\mathrm{RhB} @ \mathrm{SiO}_{2}$ and $\mathrm{C}_{16} \mathrm{~N}^{+}-\mathrm{W}_{2} \mathrm{O}_{7}{ }^{2-}-\mathrm{Eu}^{3+}$ dispersed in heptane, respectively, in which PLs of RhB and $\mathrm{Eu}^{3+}$ are sensitive to temperature, and are used as a molecular thermometer. We have succeeded in determining the temperature difference occurring in nanohybrid systems under microwave irradiation. We conclude that microwaves heat particles locally, leading to "non-equilibrium local heating”'. The heating extents are significantly varied with different particles, which can be attributed to the ability as the heat insulator contained in the nanohybrid systems. The temperature-measuring method is very important in controlling microwave heating in chemical reactions. Furthermore it should be a strong tool for elucidating the mechanism of microwave special effects. 


\section{Acknowledgements}

We thank S. Genseki and K. Hori (Tokyo Institute of Technology) for TEM observations, C. Hara (Tokyo Institute of Technology) for CHN analysis and Y. Otsuka (Tokyo Institute of Technology) for ICP-OES. This study was supported in part by a Grant-in-Aid for Scientific Research (A) 25249113, a Grant-in-Aid for Exploratory Research, Japan, the ASPIRE League Research Grant 2014 and 2015, Tokyo Tech, Research Grant of TEPCO Memorial Foundation, and the Demonstration and Standardization Project Using New Electric Devices, NEDO.

\section{Notes and references}

1 D. M. P. Mingos and D. R. Baghurst, Chem. Soc. Rev., 1991, 20, 1.

2 J. G. P. Binner, N. A. Hassine and T. E. Cross, J. Mater. Sci., 1995, 30, 5389.

3 D. Stuerga and P. Gaillard, Tetrahedron, 1996, 52, 5505.

4 X. Zhang, D. O. Hayward and D. M. P. Mingos, Chem. Commun., 1999, 975.

5 Y. Tsai, B. A. Coles, R. G. Compton and F. Marken, J. Am. Chem. Soc., 2002, 124, 9784.

6 N. E. Leadbeater and M. Marco, Angew. Chem., Int. Ed., 2003, 115, 1445.

7 D. Bogdal, M. Lukasiewicz, J. Pielichowski, A. Miciak and Sz. Bednarz, Tetrahedron, 2003, 59, 649.

8 R. K. Arvela, N. E. Leadbeater, M. S. Sangi, V. A. Williams, P. Granados and R. D. Singer, J. Org. Chem., 2005, 70, 161.

9 M. H. C. L. Dressen, B. H. P. van de Kruijs, J. Meuldijk, J. A. J. M. Vekemans and L. A. Hulshof, Org. Process Res. Dev., 2011, 15, 140.

10 D. Mochizuki, M. Shitara, M. M. Maitani and Y. Wada, Chem. Lett., 2012, 41, 1409.

11 M. Crosswhite, J. Hunt, T. Southworth, K. Serniak, A. Ferrari and A. E. Stiegman, ACS Catal., 2013, 3, 1318.

12 D. Mochizuki, R. Sasaki, M. M. Maitani, M. Okamoto, E. Suzuki and Y. Wada, J. Catal., 2015, 323, 1.

13 K. C. Westaway and R. N. Gedye, J. Microwave Power, 1995, 30, 219.
14 F. Langa, P. de la Cruz, A. de la Hoz, A. Díaz-Ortiz and E. Díez-Barra, Contemp. Org. Synth., 1997, 4, 373.

15 L. Perreux and A. Loupy, Tetrahedron, 2001, 57, 9199.

16 Wm. C. Conner and G. A. Tompsett, J. Phys. Chem. B, 2008, 112, 2110.

17 K. Nushiro, S. Kikuchi and T. Yamada, Chem. Commun., 2013, 49, 8371.

18 F. Kishimoto, T. Imai, S. Fujii, D. Mochizuki, M. M. Maitani, E. Suzuki and Y. Wada, Sci. Rep., 2015, 5, 11308.

19 M. A. Herrero, J. M. Kremsner and C. O. Kappe, J. Org. Chem., 2008, 73, 36.

20 C. O. Kappe, B. Pieber and D. Dallinger, Angew. Chem., Int. Ed., 2013, 52, 1088.

21 C. P. Kabb, R. N. Carmean and B. S. Sumerlin, Chem. Sci., $2015,6,5662$.

22 Y. Tsukahara, A. Higashi, T. Yamauchi, T. Nakamura, M. Yasuda, A. Baba and Y. Wada, J. Phys. Chem. C, 2010, 114, 8965.

23 R. K. P. Benninger, Y. Koç, O. Hofmann, J. Requejo-Isidro, M. A. A. Neil, P. M. W. French and A. J. deMello, Anal. Chem., 2006, 78, 2272.

24 S. Someya, S. Yoshida, Y. Li and K. Okamoto, Meas. Sci. Technol., 2009, 20, 025403.

25 K. Okabe, N. Inada, C. Gota, Y. Harada, T. Funatsu and S. Uchiyama, Nat. Commun., 2012, 3, 705.

26 X. Wang, O. S. Wolfbeis and R. J. Meier, Chem. Soc. Rev., 2013, 42, 7834.

27 Q. Li, Y. He, J. Chang, L. Wang, H. Chen, Y.-W. Tan, H. Wang and Z. Shao, J. Am. Chem. Soc., 2013, 135, 14924.

28 L. Tian, X. Yan, J. Xu, P. Wallenmeyer, J. Murowchick, L. Liu and X. Chen, J. Mater. Chem. A, 2015, 3, 12550.

29 F. Kishimoto, D. Mochizuki, M. M. Maitani, E. Suzuki and Y. Wada, RSC Adv., 2015, 5, 77839.

30 X. Guo, X. Liu, B. Xu and T. Dou, Colloids Surf., A, 2009, 345, 141.

31 J.-C. Champarnaud-Mesjard, B. Frit and A. Watanabe, J. Mater. Chem., 1999, 9, 1319. 